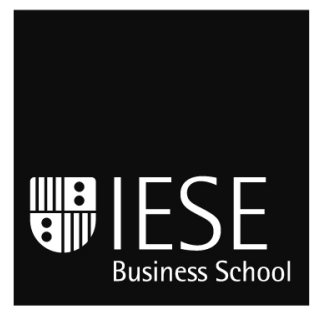

Working Paper

WP no 633

CBS

May, 2006

University of Navarra

Center for Business in Society

USING STAKEHOLDER DIALOGUE AS A SOURCE FOR NEW IDEAS:

A DYNAMIC CAPABILITY UNDERLYING

SUSTAINABLE INNOVATION

\author{
Silvia Ayuso \\ Miguel Angel Rodríguez \\ Joan Enric Ricart
}




\title{
USING STAKEHOLDER DIALOGUE AS A SOURCE FOR NEW IDEAS: A DYNAMIC CAPABILITY UNDERLYING SUSTAINABLE INNOVATION
}

\author{
Silvia Ayuso* \\ Miguel Angel Rodríguez** \\ Joan Enric Ricart**
}

\begin{abstract}
This paper attempts to gain a deeper understanding of the firm's ability to integrate stakeholder insights into the process of organizational innovation from a sustainable development viewpoint. Given the early stage of empirical research on the topic, we used an exploratory case study of two Spanish companies that have successfully learned from stakeholder dialogue and have generated innovations that are beneficial both for the company and for sustainable development in general. The evidence from the two case studies suggests the existence of two simple capabilities - stakeholder dialogue and stakeholder knowledge integration - for generating innovations in accordance with stakeholder needs. Whereas stakeholder dialogue leverages organizational resources that promote two-way communication, transparency and appropriate feedback to stakeholders, stakeholder knowledge integration relies on nonhierarchical structures, flexibility and openness to change. The paper sheds some light on the under-researched issue of linking stakeholder dialogue and sustainable innovation, and thus contributes to opening the "black box" of dynamic capabilities and advancing in the understanding of this fundamental organizational concept.
\end{abstract}

* Postdoctoral Research Fellow, IESE

** Lecturer of General Management, IESE

*** Professor of General Management, IESE

Keywords: Sustainable Development, Stakeholders, Innovation, Capabilities, Spain 


\section{USING STAKEHOLDER DIALOGUE AS A SOURCE FOR NEW IDEAS: A DYNAMIC CAPABILITY UNDERLYING SUSTAINABLE INNOVATION}

\section{Introduction}

Sustainable development will not happen without innovation. There is growing acceptance that to move towards sustainability there must be changes in the ways in which business operates and in the products and services it provides (Holliday et al., 2002). Thus, the challenge for business is to develop innovation strategies that respond to increasing environmental and social pressures, and thus consider the needs and expectations of a wide array of stakeholders (Senge and Carstedt, 2001). At the same time, sustainable development provides an opportunity to enhance competitiveness and growth, as it can become a source of inspiration for efforts at innovation, (Hall and Vredenburg, 2003; Hart and Milstein, 1999). Some researchers have already emphasized the role of stakeholder dialogue as an opportunity for facilitating innovation, and have highlighted the threats of not taking into account the views and perceptions of important stakeholders when introducing an innovation in the market (Hall and Vredenburg, 2003; Hart and Sharma, 2004; Kanter, 1999). Although the need to be open to external sources of insights and competency seems almost self-evident, there has been very little research about the relevance of stakeholder dialogue for sustainable innovation, and only a few practical experiences have been documented and commented so far (see, for example, Sabapathy et al., 2002; The Conference Board of Canada, 2002).

Dialogue with stakeholders has been studied most prominently from the stakeholder theory approach. But, as Hart and Sharma (2004) recently pointed out, current approaches do not consider "the potential for engaging stakeholders to understand "future change" or to resolve the radical uncertainty of constantly evolving knowledge." Accordingly, these and other scholars see stakeholder engagement as an organizational capability framed within the resource-based view of the firm. However, in spite of the increasing popularity of the organizational capabilities approach among researchers, capabilities themselves are often seen as "black boxes," since understanding about related managerial and organizational processes, asset positions and evolutionary paths is still at an early stage. This paper attempts to gain a deeper understanding, as well as to compile empirical data on the firm's ability to integrate stakeholder insights into the process of organizational innovation. First, we examine two theoretical approaches and analyze their contributions and short-comings in explaining the phenomenon studied: stakeholder theory and the resource-based view of the firm. After that, we describe our research methodology and present the case studies of two Spanish companies 
that have successfully learned from stakeholder dialogue and have generated innovations that are beneficial both for the company and for sustainable development in general. The empirical evidence obtained from the two cases is compared and related to the literature. Finally, we draw conclusions and remark on some limitations and implications of the research conducted.

\section{Dealing with Specific Interest Groups: Stakeholder Theory}

Stakeholder theory is concerned with the nature of the relationship between the firm and its stakeholders. Following Freeman's landmark book, stakeholders are defined as "any group or individual who can affect or is affected by the achievement of the organization's objectives." (1984, p. 46). Firms are posited to pay attention to stakeholder influence for normative and instrumental reasons. Normative explications of stakeholder theory move firm-stakeholder relations into an ethical realm, proposing that managers should consider the interests of those who have stakes in the organization. In this view, stakeholders have a legitimate interest in the firm's processes or products and these interests have intrinsic value (Donaldson and Preston, 1995). Therefore, this stream of literature prescribes that managers have a moral obligation with regard to their stakeholders and specifies correspondent ethical systems (e.g. Donaldson and Dunfee, 1999; Evan and Freeman, 1988; Freeman and Philips, 2002). By contrast, instrumental stakeholder theories predict firm behaviour on means-ends reasoning, whereby the firm pursues its interests through managing relationships with stakeholders (Jones, 1995). The instrumental orientation sees firms as addressing the interests of stakeholders who are perceived to have influence. For example, Frooman (1999) suggests the existence of four types of stakeholder influence and four types of resource relationship. Rowley (1997) describes the simultaneous influence of multiple stakeholders, and predicts firms' responses by looking at the density of the stakeholder network in relation to the centrality of the focal organization. The overall conclusion of this body of work is that managing stakeholders' interests will maximize the firm's performance (e.g. Agle et al., 1999; Berman et al., 1999; Welcomer et al., 2003).

One of the first challenges for organizations is to identify their stakeholders. Scholars usually classify stakeholders into primary and secondary groups (Clarkson, 1995; Hall and Vredenburg, 2003; Post et al., 2002; Waddock et al., 2002). The primary or core stakeholder group refers to stakeholders who are essential for the business itself to exist and/or have some kind of formal contract with the business (owners, employees, customers and suppliers). The secondary stakeholder group includes social and political stakeholders who play a fundamental role in achieving business credibility and acceptance of its activities (NGOs/activists, communities, governments and competitors). Furthermore, Driscoll and Starik (2004) broaden the stakeholder definition to include the natural environment, and Hart and Sharma (2004) add the existence of peripheral stakeholders or "fringe" stakeholders as those parties not visible and readily identifiable for the firm.

Assuming that stakeholders have been identified, the next challenge for organizations is to develop strategies for dealing with them. This is a challenge because different stakeholder groups have different, and often contradicting, goals, priorities and demands. Harrison and St. John (1996) list several examples of stakeholder management practices and suggest that the tactic chosen will depend on the strategic importance of the stakeholder for the firm. According to these authors, traditional stakeholder management techniques (buffering) attempt to satisfy stakeholder needs and/or demands, whereas partnering activities allow firms to build bridges with their stakeholders in the pursuit of common goals. Recently, some scholars have warned against the use of the term "stakeholder management," as it implies that the firm can control

2 - IESE Business School-University of Navarra 
and direct the interactions with its stakeholders (Jonker and Foster, 2002). Svendsen (1998) introduces the approach of "stakeholder collaboration," which focuses on building stakeholder relationships that are reciprocal, evolving and mutually defined. However, despite some general suggestions about the characteristics and conditions of this type of dialogue with stakeholders (see e.g. Kaptein and Van Tulder, 2003; Scholes and Clutterbuck, 1998), there has been very little empirical research about concrete stakeholder engagement mechanisms. An exception is the study by Heugens et al. (2002), who analyze the structures and processes underlying firmstakeholder relationships, and conclude that structural stakeholder integration techniques lead to legitimization of the firm, whereas processual stakeholder management practices result in learning outcomes.

Thus, stakeholder theory provides a suitable theoretical framework to analyze the relationship between business and society from a sustainable development viewpoint, since it emphasizes values such as participation, inclusion and mutual dependence (Wheeler et al., 2003). At the same time, increasing studies suggest that strengthened stakeholder relationships can result in significant competitive advantages in the form of trust, reputation and innovation (Rodriguez et al., 2002). However, stakeholder theory can only explain how to identify and engage with stakeholders for specific collaboration. In order to align stakeholders' interests and create longterm value, organizations have to develop, apply and maintain the necessary management competences and capabilities to deal with stakeholder concerns over time. To consider the concept of capabilities, we turn to the theoretical stream of the resource-based view of the firm.

\section{Distinctive Capabilities: Resource-Based View of the Firm and Dynamic Capabilities}

One of the more promising theories to evolve in the strategic management field over recent years is the resource-based view (RBV) of the firm. Focusing on a firm-level analysis, RBV suggests that differences in firm performance are primarily the result of resource heterogeneity across firms (Wernerfelt, 1984). Firms that are able to accumulate resources and capabilities that are rare, valuable, non-substitutable, and imperfectly imitable will achieve an advantage over competitors (Barney, 1991). A distinction is normally made between resources and capabilities, in that "resources are stocks of available factors that are owned or controlled by the organization and capabilities are an organization's capacity to deploy resources." (Amit and Schoemaker, 1993, p.35). Resources tend to be tradable in markets and can be divided into tangible assets, such as financial and physical capital, and intangible assets, such as human and organizational capital (Barney, 1986). By contrast, capabilities reside in routines that are intrinsically intangible and embedded in the firm, and thus cannot be traded on factor markets (Kogut and Zander, 1992).

Drawing from evolutionary theory of the firm, the dynamic capabilities approach to the firm emerged as an extension of the RBV. Dynamic capabilities are defined as "the firm's ability to integrate, build, and reconfigure internal and external competences to address rapidly changing environments." (Teece et al., 1997, p. 516). As such, they are considered as antecedent organizational and strategic routines by which managers acquire resources, modify them, integrate them, and recombine them to generate new value-creating strategies (Eisenhardt and Martin, 2000). Thus, dynamic capabilities reflect an organization's ability to achieve new and innovative forms of competitive advantage, given distinctive managerial and organizational processes, specific firms' asset positions and the evolutionary paths followed. 
Organizational innovation can be framed as a dynamic capability, since it is crucial for the renewal of organizational knowledge and the resources of firms (Lawson and Samson, 2001; Verona and Ravasi, 2003).

In order to consider the external environment of organizations, some RBV scholars argue that the conduct and performance of firms can be more fully understood by examining the network of relationships in which they are embedded. Following a relational view (Dyer and Singh, 1998) these researchers argue that idiosyncratic linkages with partners outside the firm can be a source of competitive advantage, because these relationships can enable firms to access additional resources such as financial, intellectual and human capital. Thus, the capability to engage essential stakeholders in positive relationships can give firms a competitive advantage. Some authors have related these insights from capability literature to stakeholder interests and sustainable development. Hart (1995), for instance, proposed a natural-resource-based view of the firm including environmental considerations within the RBV, while Litz (1996) developed a resource-based view of the socially responsible firm. Sharma and Vredenburg (1998) studied proactive environmental management in relation to organizational capabilities empirically, whereas Black and Härtel (2004) tested different social responsiveness capabilities of the firm. Finally, Hart and Sharma (2004) analyzed the capabilities required to address the challenges of globalized and rapidly changing markets. All these authors identified relationships between capabilities and stakeholders with regard to the elements of a sustainable company.

The significance of relationships as a valuable resource in themselves is captured in the term "social capital." Within management literature, social capital is defined as "the sum of the actual and potential resources embedded within, available through and derived from the network of relationships possessed by an individual or social unit." (Nahapiet and Ghoshal, 1998, p. 243). By means of the structural, relational and cognitive dimensions of social capital Svendsen et al. (2001) measure the quality of a firm's stakeholder relationships. Whereas the structural dimension refers to the structure of the social network in which the relationship is embedded, the relational dimension deals with the levels of mutual trust and reciprocity and the cognitive dimension reflects the levels of shared understanding and goals. Thus social capital is a broadly defined multidimensional construct that can contribute in many ways to the creation of new value for an organization. However, in order to benefit from this "stakeholder capital" in order to bring about innovation, companies have to leverage an essential resource of the built relationships: knowledge.

In fact, knowledge and learning have been widely acknowledged in the literature as the main ingredients in the creation of dynamic capabilities (Grant, 1996; Kogut and Zander, 1992; Zollo and Winter, 2002). More specifically, several scholars highlight the importance of relationships and interactions for knowledge transfer both within and across organizational boundaries. There exists an extensive literature on the use of alliances, joint ventures and networks by firms to acquire new knowledge for innovation processes (e.g. Ireland et al., 2002; Tsai and Ghoshal, 1998). However, despite the potential of stakeholder engagement as a source of knowledge, current research has not dealt with knowledge integration from stakeholders in the context of sustainable development.

\section{Research Methodology}

Given the early stage of empirical research on firms' capabilities with regard to stakeholder interaction, we used an exploratory case study research strategy, applying qualitative methods 
(Eisenhardt, 1989; Miles and Huberman, 1994). The adoption of a qualitative methodology is also consistent with the fact that dynamic capabilities are embedded in firms' organizational routines and processes (Eisenhardt and Martin, 2000) and thus are very difficult to identify through quantitative research. We selected cases of two Spanish companies as outstanding examples of companies that have initiated a dialogue with some of their stakeholders and where this dialogue has apparently resulted in important sustainable innovations: the distribution group Grupo Eroski and the savings bank Caja Navarra. Grupo Eroski has integrated workers and consumers/customers into its organizational structure since its foundation as a cooperative, and has been successful in harnessing this unique relationship for continuous innovation in accordance with its social and economic mission. Caja Navarra recently adopted an innovative strategy in human resource management and in customer relations and thus has achieved a greater involvement of the clients in the products and services offered by this financial institution. These features mean that the study of these two cases will allow us to analyze the dynamic capabilities that contribute to their capacity for sustainable innovation.

The data was collected between June and October 2005 in the form of reviews of the companies' public reports and in-depth semi-structured interviews with relevant managers. While the questions were left as open as possible, the interviewees were asked about how the company was managing the relationship with stakeholders generally, and in the case of employees or customers specifically, and how organizational innovation processes were organized. The analysis of the data collected took the form of a summary of the information in case write-ups, structured according to the components of dynamic capabilities identified by Verona and Ravasi (2003): actors, physical resources, structure and systems, and company culture. This structuring allowed us to compare similarities and differences between the two cases and identify the potential variables of interest, which were finally reduced to the categories of values, and structures and systems (see Table 1). The following section highlights the most important features of both cases with regard to company background, relations with employees and customers and innovation and knowledge management.

\section{Case Study of Grupo Eroski}

\section{Company Background}

Grupo Eroski is one of the leading Spanish distribution companies for high consumption products and services. The company has several Spanish market formats: 75 Eroski hypermarkets, 489 Eroski center supermarkets, 157 Eroski city supermarkets, 402 franchises, 22 cash \& carry depots, 208 Eroski travel agencies, 38 Eroski petrol stations, 31 FORUM sports shops, 172 If perfumeries, 2 abac leisure and culture shops, 6 food service establishments and 19 platforms. This own network is rounded off by 553 Aliprox self-service shops and other franchises. In France, Grupo Eroski has 3 hypermarkets, 18 supermarkets and 17 Eroski petrol stations. The company was born in 1969, when ten small local cooperatives from Bizkaia and Gipuzkoa merged into a new model of an egalitarian cooperative of consumers and workers. Over 35 years later, the number of owner-workers has increased from 88 to 12,298 (with a total workforce of 30,101) and the few thousand original consumer-members now number over 335,000 . The company has a market share of about 28\% in Spanish food retailing and has undergone constant growth in the last few years. Grupo Eroski is integrated into the 
cooperative business group Mondragón Corporación Cooperativa (MCC) and thus endorses the corporate values of cooperation, participation, social responsibility and innovation (MCC 2001). In addition, Grupo Eroski promotes so-called "consumer value" and invests 10\% of its annual profits in actions aimed at providing information for consumers, increasing awareness about the environment and promoting international solidarity. This budget is managed by the associated foundation, Fundación Eroski.

\section{Relations with Employees}

As a cooperative, Grupo Eroski offers its workers the chance to participate in company ownership, management and profits. Currently, 41\% of the total personnel are owner-workers and participate in the company decision-making through different governing bodies (see Figure 1). The 12,298 owner-workers elect their delegates from regionally organized Delegates' Commissions, who in turn elect members of the Social Council. The Social Council has an advisory and informative character concerning working conditions, and chairs the Preparatory Assembly. The Preparatory Assembly is an annual informative meeting of all workers to elect the delegates of the General Assembly, which is the supreme authority expressing the social will of all cooperative members, and meets at least once a year. The General Assembly approves the strategic plans of the cooperative, and nominates the Rector Council and the Social Council. The Rector Council is the body of representation, administration and governance of the cooperative. It is made up of six owner-workers and six consumer-members elected for four years, with half the members replaced every two years. It meets once a month and supervises the management, nominates the manager, and periodically controls his or her performance. Part of the cooperative participatory model was transferred in 1998 to the hypermarkets (limited companies) which the Group runs outside the Basque Country. When this occurred, hypermarket employees were offered the chance to become members of the private company GESPA (Employee Participation Management Services) and thus participate in the company's management and capital.

In accord with its cooperative mission, Grupo Eroski promotes job creation (it has a strict nolayoff policy for worker members) and invests in its employees' personal and professional development. Among the training programs conducted, the most outstanding is the Leadership Program initiated in 2003. Following a methodology designed in house, the program aimed at improving communication, affectivity and relationships between people based on the concept of "conversational competencies." Initially targeted at top managers, the training has been extended, and so far, 2,000 people with managing responsibilities have received an average three-day course. Like all bigger business organizations, Grupo Eroski has created a range of communication channels to provide workers with relevant corporate information (magazines, intranet etc.). At the same time, however, the company makes an effort at "active listening" and has developed several tools to allow employees to express themselves with regard to different topics (satisfaction surveys, $180^{\circ}$ assessments, internal call center etc.). 


\section{Figure 1}

The Organizational Structure of Grupo Eroski

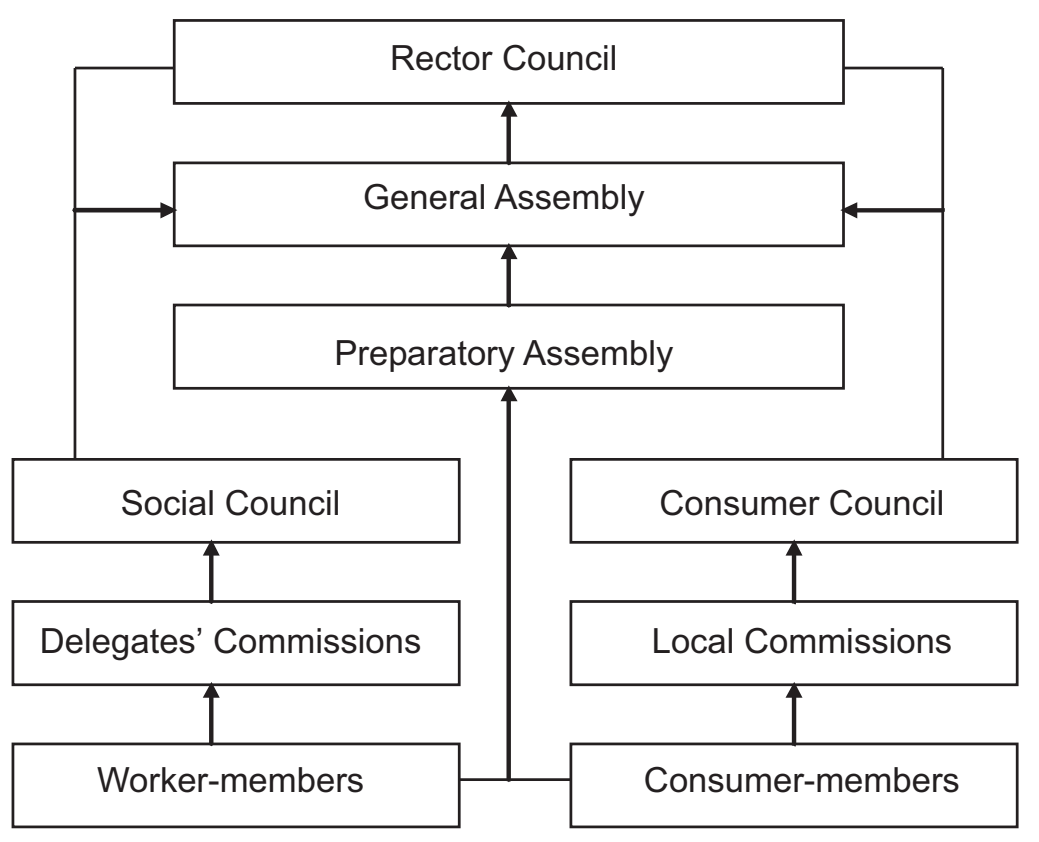

\section{Relations with Customers}

Eroski Cooperative was initially constituted with the objective of promoting consumers' economic interests and rights. Since then, the figure of the consumer has been essential for the company. Besides being considered customers of the company's sales activity, consumers are offered the option of becoming associates and participating with the owner-workers in the company decision-making process. In parallel to the governing bodies of worker-members, the 356,590 consumers-members elect their delegates from regionally organized Local Commissions, who in turn elect the members of the Consumer Council. The Consumer Council informs and advises the Rector Council in consumer issues. All consumer-members take part in the Preparatory Assemblies and elect their delegates for the General Assembly and the Rector Council. These annual meetings are also used by Eroski to receive customer feedback, in addition to other communication channels (telephone customer service, corporate web site, satisfaction surveys etc.).

Since the Eroski Foundation pursues the aim of providing useful and reliable information to consumers, it coordinates several communication and education activities, such as consumer schools, information campaigns, special advice programs, magazines and guidebooks and a consumer web site. Recently, Grupo Eroski has started to work with focus groups of selected consumers. Adapting a methodology of public participation, the company invites consumers who have actively participated in previous consumer initiatives to take part in workshops of about 20 people. Together with Eroski personnel from local shops, consumers discuss Eroski's responsibility with regard to specific issues, such as healthy lifestyle habits. 


\section{Innovation and Knowledge Management}

Grupo Eroski can be considered an innovative company with regard to its products and services, its internal processes and its management models. Apart from original strategies for pursuing market growth and expansion (e.g. participation in capital, alliances with other independent distributors in Europe, diversification) Eroski has developed several initiatives in accordance with its social-economic mission. Having been set up as a cooperative, Eroski has focused from the very beginning on the education, rights and development of its workers. A notable example is the GESPA model developed to treat non-member employees in a similar way to worker members. The commitment to improving the society in which it operates has lead Eroski to focus strongly on food goods related to health. As a consequence, the Eroski Foundation designed the education and information program "Healthy Idea," involving consumer schools, forums and magazines.

Despite the high number of innovative projects, Eroski Group has paid little attention to formal procedures for innovation and knowledge management in the past and has seemingly leaned on the creativity potential and the ability to adapt to change of its personnel. Recently, however, it started to systematize these topics. For instance, in 2003 it created a Best Practices Forum in order to validate good practices identified in different business areas and to disseminate them throughout the company. Since the beginning of 2005, Grupo Eroski has been making the effort of defining a continuous innovation process and measuring it through appropriate indicators. In this sense, a series of innovation workshops have been organized at different organizational levels, in order to gather ideas that are fed into an "innovation silo" and further studied for implementation.

\section{Case Study of Caja Navarra}

\section{Company Background}

Caja Navarra (CAN) is a savings bank founded in 2000 after a merger of two saving banks based in the region of Navarre: the Municipal Savings Bank of Pamplona (Caja de Ahorros Municipal de Pamplona) and the Savings Bank of Navarre (Caja de Ahorros de Navarra). CAN currently employs 1,300 employees and offers services to 557,000 individual and business customers through a network of 247 branch offices, 49 of them outside Navarre. Savings banks in Spain were created almost two hundred years ago with the main objective of channeling people's savings towards investment, and financing social projects in the regions where they were based. Thus, nowadays, savings banks are private non-profit-making foundations that return part of their financial gains to society in the form of charitable social projects. Accordingly, CAN has committed to investing at least 25\% of its profits in social issues via its associated foundation, Fundación Caja Navarra. Following the merger in 2000, CAN underwent a profound transformation, changing its board of directors and general manager, and initiating early retirement and staff renewal plans. Above all, CAN designed a new strategy based on the motto of "Results with differentiation" and promoting the values of customer orientation, collaboration, differentiation and innovation. CAN is the leading financial institution in Navarre with a share of $56 \%$ in deposits and $34 \%$ in loans. Its financial performance has improved, especially in the business customer sector, where the credit investment in CAN's balance has increased in two years from 10 to 35\%, with a 35\% improvement in profitability. 


\section{Relationship with Employees}

CAN underwent a drastic transformation after the merger in 2000. Before that, the firm was characterized by a bureaucratic orientation and a strong emphasis on status. The new general manager promoted a series of changes aimed at achieving less hierarchical structures and cooperation. A series of training programs were created for transmitting this cultural change and developing the necessary competencies. The members of the top management team received an individual coaching program on goals orientation and performance-based measurement. In collaboration with the University of Navarre, the executive development school (CarreraCAN) provides annual training for around 35 young staff with the potential to be promoted to positions with more responsibility. An initiative targeted at all the staff is the recently designed customer service school; MetaCAN. MetaCAN consists of two parts: a training session (Metacan 1) and the application of projects on a day to day basis in the branches (Metacan 364). The objective of this innovative training methodology is to "live" the sensations generated in customer services and reflect on how to improve relations with the client.

Parallel to these training measures, an important step in the change process of CAN has been to renew the organizational structure and move from a pyramidal organization to a circular one, with the customer located at the center. The new management model entails changes in functions and responsibilities: seven areas of responsibility have been established around the client, responsibilities and not status define result areas, exclusive attributions have disappeared and team work is encouraged (see Figure 2).

\section{Figure 2}

The Organizational Structure of Caja Navarra

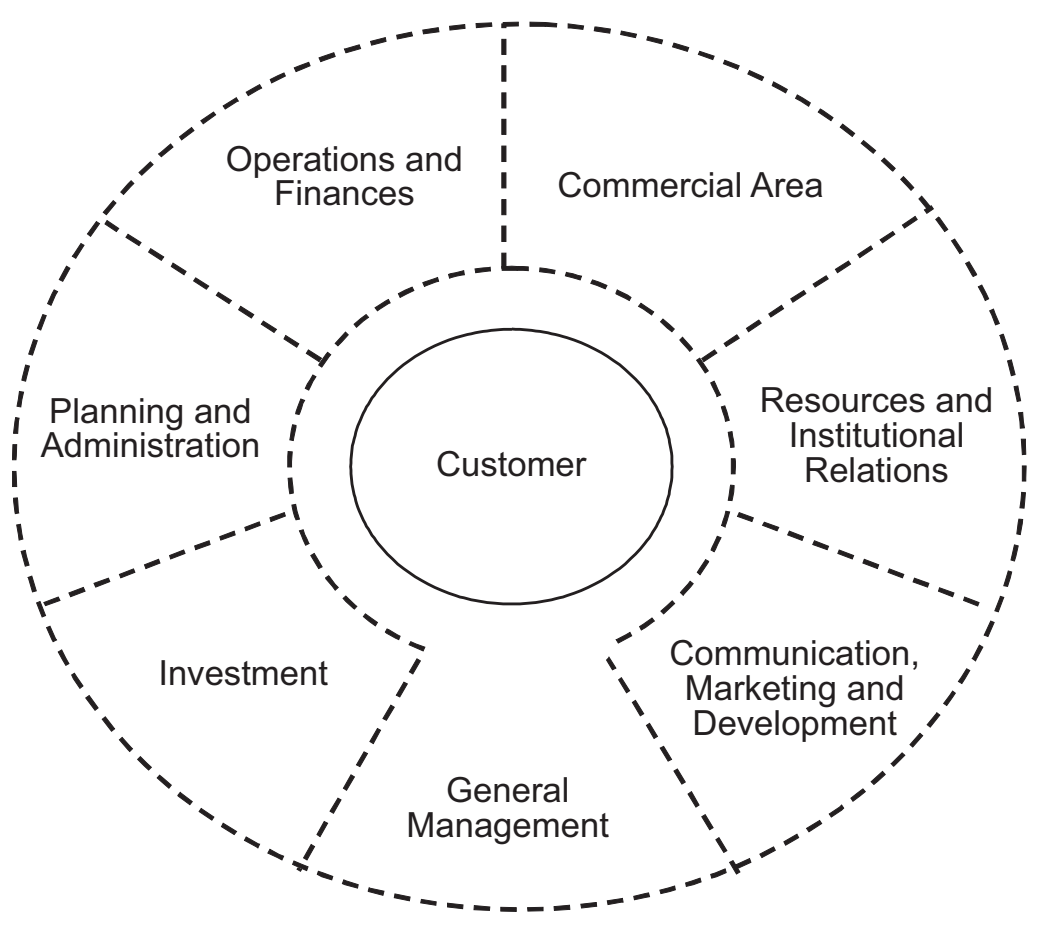




\section{Relations with Customers}

CAN uses some traditional communication channels with its customers, such as customer services and customized telephone surveys to clients. Recently, CAN adopted an innovative strategy for approaching its customers, and launched two outstanding programs: "Vialogos" and "You choose: you decide." "Vialogos" was started at the end of 2002 as an initiative targeted at business customers, a market segment where CAN had a relatively low share. In order to find out how to improve the relationship with business clients, CAN decided to ask companies their opinion about CAN's products and services. Through a first survey of 120 business owners and managers, a series of criticisms and suggestions were collected. After an exhaustive analysis, the results of the survey were presented at a meeting with 200 business people, and the general manager publicly took on ten improvement commitments for offering more complete and faster services. Months later, in a second plenary session, the general manager showed up again and reported the commitments fulfilled so far to the business community. This process has continued, alternating surveys of businesses and publicly assumed improvement commitments in the plenary meetings. The "Viàlogos" program has been consolidated as a working methodology consisting of a dialogue with business customers (specifically SMEs with more than three million euros of turnover) about their needs and expectations regarding their relationship with Caja Navarra. Business clients can express their opinions through four channels: responding to the broad annual survey that asks them about CAN's weak points, responding to the questionnaires that are handed out in the Viàlogos meetings, participating in the "Viàlogos" virtual forums, or directly informing a personal manager. The recently established "Viàlogos" Business Development Unit of CAN is in charge of analyzing all proposals and coordinating and monitoring the actions necessary for implementation. A fidelity program has been developed, and currently has reached 620 business clients. All of them are invited to the meetings, have assigned a personal manager and receive exclusively prepared reports about economic and political issues. The 120 companies with the highest turnover are members of the "Viàlogos" Club, and receive additional services besides enjoying the previously mentioned benefits.

In April 2004 CAN started the initiative "You choose: you decide" ("Tú eliges: tú decides"). It is the only experience in Spain, and as far as we know, in the world, of a financial institution that gives its customers the chance to decide about the social investments to be made. Each time a client contracts a product or service, he or she can choose between nine of CAN's lines of action through its associated foundation, where the profit generated by their transactions will be invested: research, development cooperation, environment, disabled people and assistance, heritage conservation, culture, sports and leisure, employment and entrepreneurs, and a universal option that includes all the lines of action. CAN provided specific information and training for its employees and undertook several programs of communication aimed at its customers: mailings, inclusion in the clients' magazine, brochures, a DVD/book, and personalization of bank books and cards. In addition, CAN has undertaken a broad communication campaign in the press, radio, television and Internet, and has even tried out innovative forms of communication such as theatrical plays on the street. The fact of letting customers decide on the social initiatives has substantially reoriented the action areas of the Fundación Caja Navarra: whereas before, more than 50\% of the funds were invested in culture and leisure, the majority of customers have chosen disabled people and assistance, research, environment and development cooperation. All projects financed will be audited, and detailed reports will be sent to each client of all the project activities undertaken. Also, CAN's Corporate Social Responsibility Report will include information about the activities of the CAN Foundation and the investment decisions taken by the clients. Next year, CAN plans to offer 
not only investment lines but specific projects to let the customer choose. And in the near future, the clients will be even able to participate and to follow the evolution of these projects on the spot.

\section{Innovation and Knowledge Management}

CAN's transformation process aims at delivering a more dynamic organization. Therefore, together with the new organizational structure, CAN has designed some temporary and flexible structures to generate ideas and channel knowledge creation, such as innovation workshops for young employees and multidisciplinary strategic implementation committees. These committees are multidisciplinary teams of six to ten people that are created for specific projects and are led by a top manager who is not an expert in the project issue. The objective is to study in depth strategic issues and design their implementation; for example internal communication, balanced scorecards, management by competences and so on. Since very recently, CAN has been trying to systematize its innovation efforts by generating a shared vision and a creative attitude throughout the organization.

Thanks to the changes undertaken, CAN has been very innovative not only in its organizational procedures but also towards the customers: in the last few years it has launched more than one new product a week, including products oriented to a range of different segments (young people, children, entrepreneurs, immigrants, etc.) and loan options with environmental criteria. The most remarkable innovations are the programs described earlier of "You choose: you decide" and "Vialogos." As a result of the "Vialogos" program, CAN decided to facilitate the business expansion of its customers outside the region of Navarre and has reached an agreement with thirteen Spanish savings banks. This alliance called "Vialogos Network" has the objective of providing logistic and financial services to customers of member institutions in geographical zones where these savings banks do not have branches.

\section{Discussion: Elements of the Dynamic Capability Underlying Sustainable Innovation}

According to the RVB literature, organizational capabilities are embedded in a firm's processes and are composed of routines, structures, systems, cultures etc. In our analysis of the two case studies, we looked for variables that could explain the phenomenon under study, i.e. firms' capabilities related to sustainable innovation, and we observed values and structures/systems to be the two most evident categories. Table 1 summarizes the elements identified for both case studies. Since dynamic capabilities can be regarded as a combination of simple capabilities, we will distinguish between a capacity to interact with stakeholders and access their knowledge (stakeholder dialogue) and a capacity to assimilate the insights gained from stakeholder dialogue and transform them into innovative products and operations (stakeholder knowledge integration). Next, we will discuss both capabilities with examples found in the case studies. 


\section{Table 1}

Analysis of the Dynamic Capability Elements Observed

\begin{tabular}{|l|l|l|}
\hline \multicolumn{1}{|c|}{ Company } & \multicolumn{1}{|c|}{ Grupo Eroski } & \multicolumn{1}{c|}{ Caja Navarra } \\
\hline Values & $\begin{array}{l}\text { Cooperation, participation, social } \\
\text { responsibility, consumer value, } \\
\text { innovation }\end{array}$ & $\begin{array}{l}\text { Customer orientation, collaboration, } \\
\text { differentiation, innovation }\end{array}$ \\
\hline $\begin{array}{l}\text { Employee-oriented } \\
\text { structures and } \\
\text { systems }\end{array}$ & $\begin{array}{l}\text { Democratic organizational structure } \\
\text { (Delegates' Commissions, Preparatory } \\
\text { Assembly), Leadership Program, "active } \\
\text { listening" tools }\end{array}$ & $\begin{array}{l}\text { Flat circular organizational structure } \\
\text { (responsibility over status), training } \\
\text { programs }\end{array}$ \\
\hline $\begin{array}{l}\text { Customer-oriented } \\
\text { structures and } \\
\text { systems }\end{array}$ & $\begin{array}{l}\text { Democratic organizational structure } \\
\text { (Local Commissions Preparatory } \\
\text { Assemblies), "active listening" tools, } \\
\text { focus groups of selected consumers }\end{array}$ & $\begin{array}{l}\text { "Viàlogos" methodology for business } \\
\text { customers, decision about CAN's social } \\
\text { investments ("You choose: you decide" } \\
\text { initiative), "active listening" tools }\end{array}$ \\
\hline $\begin{array}{l}\text { Innovation-oriented } \\
\text { structures and } \\
\text { systems }\end{array}$ & $\begin{array}{l}\text { Democratic organizational structure, } \\
\text { best practices forum, innovation } \\
\text { workshops }\end{array}$ & $\begin{array}{l}\text { Flat circular organizational structure, } \\
\text { strategic implementation committees, } \\
\text { innovation workshops, innovation task } \\
\text { force }\end{array}$ \\
\hline
\end{tabular}

In the case of both companies, we find a high investment in engaging in dialogue with two primary stakeholders: employees and customers. Whereas Grupo Eroski represents an extreme case of democratic management involving both workers and consumers, CAN recently changed its business strategy towards a stronger relationship with customers and employees. In the absence of shareholders, these two stakeholders, employees and customers, constitute the most relevant interest groups for the companies in the case studies, with whom they interact most often and who most affect or are affected by the company. As employees and customers are also citizens, the close relationship with them ensures a link with broader society.

The significant feature of the relationships established with employees and customers is their aim to shift from a one-way communication to an interactive dialogue. Dialogue can be understood as an exchange of views and opinions. Rather than attempt to influence or coerce others, dialogue focuses on listening deeply and with empathy, expressing hidden assumptions, focusing on common interests, and searching for conceptual breakthroughs (Isaacs, 1999). Besides providing information and training, both companies examined in the case studies use a range of different tools to allow a two-way communication with the stakeholders. They do not only rely on traditional, passive systems such as mail boxes or call centers, but also use active systems of finding out the needs and suggestions of employees and customers. Eroski Group ensures this above all by means of its special organizational structure and its numerous meetings. CAN, for example, has developed a very efficient interactive communication channel with its business customers via the "Vialogos" methodology. An honest dialogue also relies on accurate and transparent information, and it can be observed that both companies studied have in place several communication systems to spread transparent information. Examples are the Preparatory Assemblies for owner-workers and consumer-members of Grupo Eroski and CAN's reports for "Vialogos" and "You choose: you decide" clients. Finally, both cases provide appropriate feedback to stakeholders who participate in the dialogue offered. Whereas Grupo Eroski's democratic functioning allows owner-workers and consumer-members to vote and take part in the company decision-making process, CAN found innovative ways to let the customers participate in the product or product shaping and decide on the company's social investments. 
But together with this stakeholder dialogue capability, we can also observe in both companies how the relationships established with their main stakeholders facilitate the access and transfer of relevant knowledge for sustainable innovation. In this sense, both companies studied have generated innovations targeted at satisfying the needs and expectations of employees and customers. The multiple communication channels established with stakeholders provide the opportunity for the firms to access creative and practical knowledge that is critical to developing innovative ideas. In addition, the companies' structures and systems to foster innovation illustrate certain features that are important for integrating stakeholder knowledge. In both companies we find non-hierarchical structures that favor direct communication and proximity between people: the democratic structure in Eroski and the flat circular structure in CAN. Furthermore, both companies studied have in place flexible structures and systems that facilitate the development and implementation of new ideas. In the case of Grupo Eroski, the informal relationships resulting from the cooperative structure have served as a breeding ground for many organizational innovations. In CAN, the multidisciplinary strategic implementation committees are a paradigmatic example of gathering together the viewpoints of different business departments and hierarchical levels in order to develop innovative proposals. Finally, both companies promote dynamism and openness to change among their organizational members. While Grupo Eroski's participation system of workers and consumers requires continuous discussions and reconsiderations of organizational issues, CAN recently undertook a major effort to bring about a shift in people's mental models towards more willingness to change.

Thus, stakeholder dialogue and stakeholder knowledge integration can be regarded as the capabilities necessary to capture stakeholder knowledge and transform it into innovative products, services, processes or strategies (see Figure 3). Both organizational capabilities contribute to the firm's dynamic capability of sustainable innovation, since the stakeholder knowledge accessed through dialogue will only impact on innovation if such knowledge can be assimilated by the firm. Organizational capabilities are based on intangible company resources but can be perceived through related phenomena such as existing values, structures and systems. Values are essential factors for developing a capability as they will guide the structures and systems designed and influence people's behavior in the form of an organizational culture. However, successful structures and systems can in turn influence the existing values and culture of an organization and become organizational routines. This becomes clear in the company cases chosen. In Grupo Eroski the cooperative based values have impregnated the organization's functioning from the beginning, but are reinterpreted periodically to integrate new demands from workers and consumers. CAN is trying to promote a change in the organizational culture by introducing different new structures and systems that pursue a stronger commitment by employees and a closer relationship with customers. In conclusion, the elements of the sustainable innovation capability observed are in a dynamic equilibrium. Values, structures and systems give continuous feedback to each other and their coherent interplay contributes to the firms' evolving capacity for sustainable innovation. Ultimately, the resulting innovations in the form of new products, services, processes or strategies, will contribute to the creation of new value for the firm and for its stakeholders, which in turn will impact on the existing organizational resources and capabilities. 


\section{Figure 3}

Dynamic Capability Underlying Sustainable Innovation
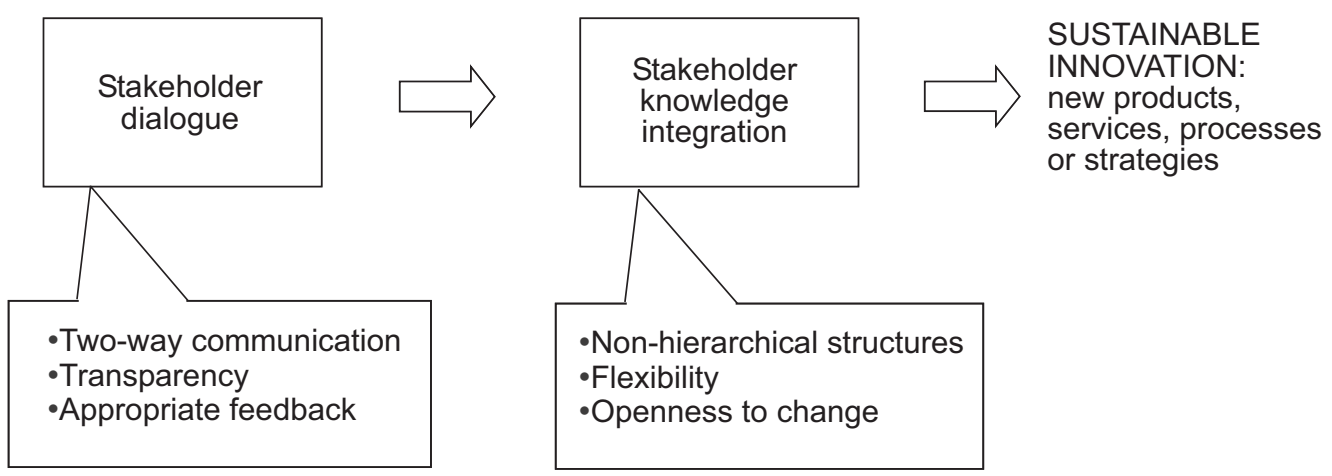

\section{Conclusions}

The purpose of this paper was to shed some light on the under-researched issue of linking stakeholder dialogue and sustainable innovation. The review of the literature showed that there is a need for theoretical and empirical research on this important issue. Stakeholder theory proposes a perspective of the firm that essentially incorporates the wider environment, i.e. the firm must learn to understand the needs, expectations and values of groups previously perceived to be external to the company: stakeholders. However, stakeholder theory focuses more on elements influencing the organizational relationships with stakeholders and considers to a lesser extent the outcomes of those relationships, such as learning and innovation. The RBV approach considers innovation as a result of firm-specific resources and capabilities. To the extent that these resources and capabilities are unique, rare, difficult to imitate and nonsubstitutable, they confer sustained competitive advantage to the firm. That means that a firm can achieve a higher organizational performance if it is capable of managing collaborative relationships with its diverse stakeholders and at the same time effectively channeling the knowledge assets obtained into its innovation processes. However, an explicit examination of this (dynamic) capability underlying sustainable innovation has not been carried out so far.

The case studies of two Spanish firms allow the identification of some of the elements of this capacity for generating innovations in accordance with stakeholder needs: the simultaneous presence of two simple capabilities - stakeholder dialogue and stakeholder knowledge integration. The evidence from the two case studies furthermore suggests certain characteristics of these organizational capabilities. Whereas stakeholder dialogue leverages company resources that promote two-way communication, transparency and appropriate feedback to stakeholders, stakeholder knowledge integration relies on non-hierarchical structures, flexibility and openness to change. However, the organizational resources on which the capabilities are built have to be considered as interrelated and able to influence one another. In this sense, Grupo Eroski illustrates the case of capabilities that evolve over time and become embedded in organizational culture and routines, whereas CAN shows that capabilities can be the result of deliberate investments in designing and promoting specific values and structures/systems. 
The fact that the two companies studied are rather special cases of companies without shareholders might limit the results of the present research. Although the selected case studies illustrate very well different ways of engaging with employees and customers, it is questionable if this form of stakeholder dialogue also works in the presence of shareholders. Thus, future research could explore sustainable innovation as a response to the demands of other kinds of stakeholders - primary ones such as owners or suppliers, and secondary ones such as NG0s or local communities. Other detailed exploratory case studies could provide a fuller picture of the complex processes underlying sustainable innovation. Also, the concept of dynamic capability identified in this paper could be refined, validated and tested using other research methods, including surveys and quantitative studies. 


\section{References}

Agle, B.R., Mitchell, R.K. and Sonnenfeld, J.A. (1999), "Who matters to CEOs? An investigation of stakeholders' attributes and salience, corporate performance and CEO values," Academy of Management Journal, Vol. 42 No. 5, pp. 507-525.

Amit, R. and Schoemaker, P.J.H. (1993), "Strategic assets and organizational rent," Strategic Management Journal, Vol. 14 No. 1, pp. 33-46.

Barney, J.B. (1986), "Strategic factor markets: Expectations, luck, and business strategy," Management Science, Vol. 32 No. 10, pp. 1231-1241.

Barney, J. (1991), "Firm resources and sustained competitive advantage," Journal of Management, Vol. 17 No. 1, pp. 99-120.

Berman, S.L., Wicks, A.C., Kotha, S. and Jones, T.M. (1999), "Does stakeholder orientation matter? The relationship between stakeholder management models and the firm's financial performance," Academy of Management Journal, Vol. 42 No. 5, pp. 488-506.

Black, L.D. and Härtel, C.E.J. (2004), "The five capabilities of socially responsible companies," Journal of Public Affairs, Vol. 4 No. 2, pp. 125-144.

Clarkson, M.B.E. (1995), "A stakeholder framework for analyzing and evaluating corporate social performance," Academy of Management Review, Vol. 20 No. 1, pp. 92-117.

Donaldson, T. and Dunfee, T.W. (1999), Ties That Bind: A Social Contracts Approach to Business Ethics, Harvard Business School Press, Boston MA.

Donaldson, T. and Preston, L.E. (1995), "The stakeholder theory of the corporation: concepts, evidence, and implications," Academy of Management Review, Vol. 20 No. 1, pp. 65-91.

Driscoll, C. and Starik, M. (2004), "The primordial stakeholder: Advancing the conceptual consideration of stakeholder status for the natural environment," Journal of Business Ethics, Vol. 49 No. 1, pp. 55-73.

Dyer, J.H. and Singh, H. (1998), "The relational view: cooperative strategy and sources of interorganizational competitive advantage," Academy of Management Review, Vol. 23 No. 4, pp. 660-679.

Eisenhardt, K.M. (1989), "Building theories from case study research," Academy of Management Review, Vol. 14 No. 4, pp. 532-550.

Eisenhardt, K.M. and Martin, J.A. (2000), “Dynamic capabilities: What are they?" Strategic Management Journal, Vol. 21 No. 10/11, pp. 1105-1121.

Evan, W.M. and Freeman, R.E. (1988), "A stakeholder theory of the modern corporation: Kantian capitalism," in Beauchamp, T. and Bowie, N. (Eds.), Ethical Theory and Business, Prentice Hall, Englewood Cliffs, NJ, pp. 75-93.

Freeman, R.E. (1984), Strategic Management: A Stakeholder Approach, Pitman, Boston.

Freeman, R.E. and Philips, R.A. (2002), "Stakeholder theory: a libertarian defence," Business Ethics Quarterly, Vol. 12 No. 3, pp. 331-349. 
Frooman, J. (1999), “Stakeholder influence strategies," Academy of Management Review, Vol. 24 No. 2, pp. 191-205.

Grant, R.M. (1996), "Prospering in dynamically-competitive environments: Organizational capability as knowledge integration,” Organization Science, Vol. 7 No. 4, pp. 375-387.

Hall, J. and Vredenburg, H. (2003), "The challenges of innovating for sustainable development," MIT Sloan Management Review, Vol. 45 No. 1, pp. 61-68.

Harrison, J.S. and St. John, C.H. (1996), "Managing and partnering with external stakeholders" Academy of Management Executive, Vol. 10 No. 2, pp. 46-60.

Hart, S.L. (1995), “A natural-resource-based view of the firm," Academy of Management Review, Vol. 20 No. 4, pp. 986-1014.

Hart, S.L. and Milstein, M.B. (1999), "Global sustainability and the creative destruction of industries,” Sloan Management Review, Vol. 41 No. 1, pp. 23-33.

Hart, S.L and Sharma, S. (2004), "Engaging fringe stakeholders for competitive imagination," Academy of Management Executive, Vol. 18 No. 1, pp. 7-18.

Heugens, P., Van den Bosch, F. and Van Riel, C. (2002), "Stakeholder integration: Building mutually enforcing relationships," Business \& Society, Vol. 41 No.1, pp. 36-60.

Holliday, C.0., Schmidheiny, S. and Watts, P. (2002), Walking the Talk. The Business Case for Sustainable Development, Greenleaf Publishing Limited, Sheffield, UK.

Ireland, R.D., Hitt, M.A. and Vaidyanath, D. (2002), "Alliance management as a source of competitive advantage,” Journal of Management, Vol. 28 No. 3, pp. 413-446.

Isaacs, W. (1999), Dialogue and the Art of Thinking Together, Currency, New York.

Jones, T.M. (1995), "Instrumental stakeholder theory: A synthesis of ethics and economics," Academy of Management Review, Vol. 20 No. 2, pp. 404-437.

Jonker, J. and Foster, D. (2002), "Stakeholder excellence? Framing the evolution and complexity of a stakeholder perspective of the firm," Corporate Social Responsibility and Environmental Management, Vol. 9 No. 4, pp. 187-195.

Kanter, R.M. (1999), "From spare change to real change: The social sector as beta site for business innovation," Harvard Business Review, Vol. 77 No. 3, pp. 122-132.

Kaptein, M. and Van Tulder, R. (2003), "Toward effective stakeholder dialogue," Business and Society Review, Vol. 108 No. 2, pp. 203-224.

Kogut, B. and Zander, U. (1992), "Knowledge of the firm, combinative capabilities, and the replication of technology," Organization Science, Vol. 3 No. 3, pp. 383-397.

Lawson, B. and Samson, D. (2001), "Developing innovation capability in organizations: a dynamic capabilities approach," International Journal of Innovation Management, Vol. 5 No. 3, pp. 377-400.

Litz, R.A. (1996), "A resource-based-view of the socially responsible firm: Stakeholder interdependence, ethical awareness, and issue responsiveness as strategic assets," Journal of Business Ethics, Vol. 15 No. 12, pp. 1355-1563. 
Miles, M.B. and Huberman, A.M. (1994), Qualitative Data Analysis, $2^{\text {nd }}$ edition, Sage Publications, London.

MCC, Mondragón Corporación Cooperativa (2001), The History of an Experience, MCC (available at http://www.mondragon.mcc.es/ing/quienessomos/historiaMCC_ing.pdf).

Nahapiet, J. and Ghoshal, S. (1998), "Social capital, intellectual capital and the organizational advantage," Academy of Management Review, Vol. 23 No. 2, pp. 242-266.

Post, J.E., Preston, L.E. and Sachs, S. (2002), "Managing the extended enterprise: The new stakeholder view,” California Management Review, Vol. 45 No. 1, pp. 6-28.

Rodríguez, M.A., Ricart, J.E. and Sánchez, P. (2002), "Sustainable development and the sustainability of competitive advantage: A dynamic and sustainable view of the firm," Creativity and Innovation Management, Vol. 11 No. 3, pp.135-146.

Rowley, T. J. (1997), "Moving beyond dyadic ties: A network theory of stakeholder influences," Academy of Management Review, Vol. 22 No. 4, pp. 887-910.

Sabapathy, J., Swift, T., Weiser, J. and Polycarpe, M. (2002), Innovation through Partnership, Institute of Social and Ethical Accountability, London.

Scholes, E. and Clutterbuck, D. (1998), "Communication with stakeholders: An integrated approach,” Long Range Planning, Vol. 31 No. 2, pp. 227-238.

Senge, P.M and Carstedt, G. (2001), "Innovating our way to the next industrial revolution," MIT Sloan Management Review, Vol. 42 No. 2, pp. 24-38.

Sharma, S. and Vredenburg, H. (1998), "Proactive corporate environmental strategy and the development of competitively valuable organizational capabilities," Strategy Management Journal, Vol. 19 No. 8, pp. 729-753.

Svendsen, A. (1998), The Stakeholder Strategy: Profiting form Collaborative Business Relationships, Berrett-Kohehler Publishers, San Francisco.

Svendsen, A.C., Boutilier, R.G., Abbott, R. and Wheeler, D. (2001), Measuring the Business Value of Stakeholder Relationships, Part One, Centre for Innovation in Management, Simon Fraser University, Vancouver, BC (available at www.cica.ca).

Teece, D.J., Pisano, G. and Shuen, A. (1997), "Dynamic capabilities and strategic management," Strategic Management Journal, Vol. 18 No. 7, pp. 509-533.

The Conference Board of Canada. (2002), Linking Social Accountability Management and Organizational Innovation: A "New" Approach to Value Creation, Industry Canada (available at: http://strategis.ic.gc.ca/epic/internet/incsr-rse.nsf/en/rs00090e.html).

Tsai, W. and Ghoshal, S. (1998), "Social capital and value creation: The role of intrafirm networks," Academy of Management Journal, Vol. 41 No. 4, 464-476.

Verona, G. and Ravasi, D. (2003), "Unbundling dynamic capabilities: an exploratory study of continuous product innovation," Industrial and Corporate Change, Vol. 12 No. 3, pp. 577606.

Waddock, S.A., Bodwell, C. and Graves, S.B. (2002), "Responsibility: The new business imperative," Academy of Management Executive, Vol. 6 No. 2, pp. 132-148. 
Welcomer, S.A., Cochran, P.L., Rands, G. and Haggerty, M. (2003), "Constructing a web. Effects of power and social responsiveness on firm-stakeholder relationships," Business and Society, Vol. 42 No. 1, pp. 43-82.

Wernerfelt, B. (1984), “A resource-based view of the firm," Strategic Management Journal, Vol. 5 No. 2, pp. 171-180.

Wheeler, D., Colbert, B. and Freeman, R. E. (2003), "Focusing on value: Reconciling corporate social responsibility, sustainability and a stakeholder approach in a network world," Journal of General Management, Vol. 28 No. 3, pp. 1-28.

Zollo, M. and Winter, S.G. (2002), "Deliberate learning and the evolution of dynamic capabilities,” Organization Science, Vol. 13 No. 3, pp. 339-351. 